\title{
Images of Care, Boundaries of the State: Volunteering and Civil Society in Czech Health Care
}

\section{Rosie Read}

Rosie Read is Senior Lecturer in Sociology and Anthropology at Bournemouth University, UK. She has conducted a number of ethnographic research projects in the Czech Republic and the UK. Her publications explore issues of gender and care work, volunteering, welfare transformation and the state.

\section{Acknowledgments}

I am grateful to the editors of this special issue for their helpful feedback on earlier drafts of this article. I also thank the anonymous reviewers for their comments.

Word count: 8,216 


\begin{abstract}
This article examines how images of the state are negotiated and projected in Czech health care volunteering. Despite two decades of institutional reform which has distanced health care from central government and facilitated the involvement of civil society in health provisions, hospitals and the professional care provided by doctors and nurses continue to be widely imagined as a domain of intensified state authority - a legacy of state socialism. I show how this image of the state provides the legitimation for hospital volunteering programs. These seek to provide an alternative, non-medical form of patient care, and are represented as independent from and complementary to conventional hospital care. I explore attempts by actors within NGOs, hospitals and local government in three Czech volunteer programs to generate hospital volunteering as civil society, thereby reproducing the boundary between state and non-state which characterized civil society discourses of the 1990s in the region. Yet unlike these discourses and the anthropological analyses they have informed, this process of boundary making does not constitute the state and civil society as inevitably antagonistic or competitive entities.
\end{abstract}

Keywords: state, care, volunteering, civil society, health, welfare, ethnography 


\section{Introduction}

In Central and Eastern Europe during the 1990s, a dominant notion of civil society came to prominence. Contained within it was a representation of the state writ large. This was of course the socialist state that in much civil society discourse was projected as domineering or authoritarian, quashing political and cultural dissent and insisting on society's compliance with official Marxist-Leninist ideology. During the 1980s, civil society was a key reference point for dissidents in the region registering their opposition to state socialism. In the post1989 period, civil society became a major project, as former dissidents were elevated to new positions of political power and their perspectives on socialism and civil society taken to be broadly representative of wider populations. Donor agencies from Western Europe and North America collaborated with new governments in the region to guide, shape, invest in and implement civil society as part of a wider goal of democratization. Non-governmental organizations (NGOs) were taken to be paradigmatic emblems of civil society (Hemment 2007; Sampson 1996; Wedel 2001). As Hann (1996) has argued, this model of civil society was a narrow, liberal-individualist one. It tended to assume a fundamental boundary, and antagonism, between civil society and the state. Earlier, more nuanced post-Enlightenment thinking about civil society in how it conceived of participation, solidarity, and the relationship between political and economic realms were reduced to a simplistic state-society dichotomy (c.f.: Alexander 2006; Mamdami 1996: 13-16).

Since the mid 1990s legislative frameworks for welfare and social security have been substantially reformed in many parts of the region. During the socialist period, state agencies took a fairly exclusive role in providing a range of forms of social protection. Now, the picture is far more mixed, as NGOs, church and community groups and profit-making companies are involved in providing welfare services funded from a range of government, 
private, national and international sources (Read and Thelen 2007; Hemment 2007; Caldwell 2004). These developments broadly mirror those in other regions too, such as Western Europe and parts of the Third World (see for instance Clarke et al. 2007, c.f.: Trouillot 2001; 132). This article explores the continuing resonance of ideas about civil society and the boundaries of the state in one such altered context of welfare; health care in the Czech Republic.

In institutional terms, the post-1989 period has seen Czech health care substantially de-centralized and privatized, such that health services are far less directly controlled by central government than during the socialist period. Nonetheless, hospital care continues to be widely imagined as a domain of the state; an expert field that continues to be emblematic of the relationship between the socialist state and its citizens. These images of the state within hospital medicine are central to the rationale for hospital volunteering programs. First developed in the late 1990s, volunteering programs aim to bring citizens onto hospital wards to provide company and support for patients. This volunteered care is conceived in terms of civil society, as a form of patient care distinct from that provided by medics.

Following Thelen, Vetters and von Benda-Beckmann (this volume), I approach 'the state' relationally in this article. I am not concerned with whether health care provision is or is not 'really' the state, nor whether civil society in the form of volunteering can be conceived of as something outside of the state. My interest is in how a boundary between the state and civil society is created in relationships between actors involved in hospital volunteering, and how this boundary becomes productive - how it brings new forms of care into being. As Timothy Mitchell observes:

The line between state and society is not a perimeter of an intrinsic entity, which can be thought of as a free-standing object or actor. It is a line drawn internally, within the 
network of institutional mechanisms through which a certain social and political order is maintained (Mitchell 1991: 90).

I explore this 'line' ethnographically, focusing on how notions of the state and civil society are mediated within relationships between hospital managers, volunteer coordinators and local government officials in three urban contexts of hospital volunteering - Prague, Ustínad-Labem and Ostrava ${ }^{1}$. Through these relationships, hospital volunteering becomes recognizable as civil society by being produced as different to the state. Yet contrary to previous analyses of civil society discourses in the region (e.g., Hann 1996; Sampson 1996; Wedel 2001; Hemmet 2007), I argue that this boundary does not mark antagonism or competition between the state and civil society. Instead, it results from a productive cooperation between different actors in NGO and public sector positions who seek to bring into being new forms of 'non-state' care to complement what is seen as state care.

\section{Health care during socialism, and after}

The universal availability of modern health care provision was a central tenet of state socialism in Czechoslovakia. After the communist party took power in 1948, a period of rapid modernization of health care took place. Health care insurance schemes were expanded to include the vast majority of the population by the early 1950's. Hospitals, clinics and other medical facilities were constructed in rural and industrial areas where pre-war access to health services had been basic and limited. Ownership and control of private and charitable health care facilities were transferred to state authorities. The expansion of health care was projected as integral to the development of socialist modernity, and socialist leaders placed great emphasis on the potential of science and medical research to solve health problems, and thereby bring about a healthier and more productive society (Inglot 2008; Štich 1954). Scientific research and its continuous implementation within medical practice for the purpose 
of health improvement was seen as inherently progressive, provided that this process was rid of its pre-war bourgeois distortions and carried out in a planned manner under the control of the state. Science was also strongly incorporated into how the state identified and acted to address health problems. Leading medical scientists, doctors and experts were recruited to work with politicians and officials in central and regional government to direct health policies. Scientific idioms of objectivity, neutrality and quantification were common to the ways in which state officials informed and engaged the public in matters of health. The socialist health care system proved remarkably effective at tackling and eliminating some of the widespread health problems affecting the post-war population, such as high rates of infectious disease and infant mortality. In the two decades after the Second World War, Czechoslovakia was ranked among the best in the world in internationally compiled health indicators (Štich 1954).

It was in the late socialist period that various problems in the health care system became more publically visible. The first public opinion survey on perceptions of health care in the 1980s revealed citizens' criticisms of certain aspects of the health care system, such as the hidden system of gifts and bribes to doctors and other medical practitioners, the fact that certain political and social groups were provided privileged access to health care (e.g., politicians, the armed forces), lack of choice of doctor, impersonal treatment by medical professionals and the suppression of health information. It was routine for doctors not to discuss patients' diagnoses and their implications with them, and more generally, state agencies were highly selective about which health statistics data could be publicly disseminated, usually releasing them only when they implied positive improvement (Jaroš et al. 2005: 199). Thus some time before November 1989, there was a growing perception amongst politicians and the public that the system of health provision was inadequate. Protestors called for health care reform even during the brief Velvet Revolution, which 
heralded the end of the socialist government, and many doctors were active participants in pushing for changes in its immediate aftermath. Reform also was high on the agenda of the new post-Velvet Revolution government, which proposed radical and wide-ranging transformation of health care as early as December 1990. Politicians perceived the system of health services as too rigid and inflexible, unable to respond to the country's health needs. They wanted to introduce new forms of resourcing, managing and ensuring the overall quality of health services that would address contemporary health problems more effectively and respond to public concerns about political interference in health care, inequity of provision and lack of choice.

What was proposed was consistent with the liberal market principles that had oriented much other political and economic reform at the time. There were several key elements of the reforms, the most radical of which were implemented in the early 1990s. Firstly, health care was no longer to be financed from general taxation, but through a compulsory national insurance system, comprising contributions from employers, employees and the state. This so called neo-Bismarckian (see for instance Jaroš et al. 2005: 212; Marree and Groenewegen 1997), pluralist model of funding health services was characteristic of other Western European states as well as pre-war Czechoslovakia, a period of history that was increasingly idealized as something of a national golden age. It was intended to de-politicize the process by which health facilities were resourced, enabling the creation of health insurance companies operating at a remove from central government which would administer the redistribution of finance to health providers on a fee-for-service basis. It sought to promote the entry of new health care services (run by NGOs, church-based organizations, private companies, etc.) to what politicians hoped would become a more competitive, market-based economy of health provision. The state would continue to guarantee all citizens' access to 
health care, but would do so through a new system of financing and legally regulating health facilities and services, rather than through monopolistic ownership of them.

Secondly, regional and district health authorities, to which all hospitals, clinics and other services had previously been strictly accountable, were abolished. Health providers were given a much greater degree of financial and managerial autonomy within a broad form of regulation created by their contract with health insurance companies. Thirdly, the reforms introduced principles of individual choice and responsibility. Individual patients were endowed with the freedom to choose their own doctor and health facility and citizens were to assume greater responsibility for their health. Thus individual patients, communities, NGOs, charities and profit making companies, were all become more active participants in health care (Jaroš et al. 2005).

Enacted in the early 1990s, these reforms were complemented by those in other areas. Reforms to the Civil Code defined civil society organizations in law, whilst devolution of central government powers to regional authorities gave the latter greater responsibility for providing health and social care services. The 2006 Social Services Act also facilitated a wider range of social care services and providers. The cumulative effect was momentous in terms of stimulating the creation of new networks and organizations. The 1990s and 2000s saw the emergence of different approaches and new activities within health and social care domain. These developments also spurred discussion and criticism of health and social care during the socialist period, and civil society activity was often concentrated in those areas in which such established provision was seen as insufficient. This was the context in which hospital volunteering emerged. 


\section{Hospital volunteering as civil society}

In 2003, a new Czech law was introduced that provided legal recognition of the category of activity known as volunteering (dobrovolnictvi). It sought to distinguish this activity from paid work and define how it could take place in a range of different settings, including health and social care organizations (Tutr and Tošner 2003). Prior to 2003, a number of civil society organizations had been managing and promoting their own volunteer schemes and pushing for legal recognition of volunteering for some years. They particularly wished to dissociate it from voluntary work and other forms of public participation of the socialist period (Read 2010). From the perspective of the emerging NGO sector as well as some academic researchers in the late 1990s (e.g., Frič 2001), voluntary work during socialism had been 'involuntary volunteering' - overly reliant on enforcement by state authorities and a form of coercion. As two prominent leaders of the Prague based National Volunteer Center wrote,

The tradition of voluntary work was violently disrupted under the totalitarian regime and the activities of all forums of independent organizations were purposefully and systematically reduced or completely subordinated to the leadership of the state and the communist party and placed under strict control...those which remained independent were surveilled by the state and liquidated. The property of foundations and clubs was confiscated and the ranks of democratically oriented people were investigated and imprisoned (Tošner and Sozanská 2006: 30).

Volunteering needed to be rehabilitated as NGOs found it widely discredited amongst the Czech population. That entailed endorsing voluntary activity as an expression of individual free will and personal choice, free from state influence. As one leading activist and consultant in the area of hospital volunteering explained, volunteering is "not only about good will, but [also] free will.” 
This vision of volunteering, embodied within the 2003 law, was more broadly consistent with the arguments of proponents of civil society in the country. Vaclav Havel, a dissident during the socialist period and first president of (what became) the Czech Republic in the post-1989 period had portrayed the socialist state as bent on controlling all aspects of social life, quashing freedom of thought and social and cultural diversity (e.g., Havel 1990; c.f., Hann and Dunn 1996). He further argued that the "various political shifts and upheavals within the communist world all have one thing in common: the undying urge to create a genuine civil society” (in Wedel 2001; 85 - my emphasis). To become 'genuine,' civil society had to be separate to the state in ideological and organizational terms.

Such ideas about civil society permeated and oriented hospital volunteering programs from their inception. The first of these began to emerge in the late 1990s and by the time of my fieldwork in 2008, dozens of volunteering programs were in operation in large and small hospitals across the Czech Republic. Alongside this, volunteering projects were also functioning or being established in old people's homes, children's homes and residential institutions for the physically disabled and mentally ill. The national reforms to health structures and health and social care provision discussed above were an important factor for encouraging and enabling these developments. But it is also important to highlight here why volunteering programs emerged specifically in health and social care settings. What was it about institutions like hospitals that made them the focus for volunteering? And what representations of the state were implicated in the momentum behind these programs?

In recounting to me how the first volunteer program was established in a large Prague hospital, the director of the Czech National Volunteer Centre described the children's oncology ward that was the initial focus for volunteers' activities. The children, as patients undergoing treatment, inhabited a grey, clinical space. They sat or lay in rooms with no pictures on the walls and few toys to play with. The predominant quiet of the ward was 
broken only by the clicking sound of medical professionals' shoes as they walked in and out of rooms and up and down corridors, carrying files or medical equipment or pushing trolleys. No hospital staff had time to spend playing with the resident children, or providing respite or comfort to them, or their parents with them. Whilst children received the highest quality specialist care in this unit, recognized nationally and internationally, this professionalism seemed to generate a gloomy, stifling and depressing atmosphere for its patients. The volunteering program, the director went on, dramatically changed this. Volunteers brought new toys, paints, musical instruments and games with them to the oncology department. They engaged children in individual and group activities that were fun and lively. Children's paintings and pictures hung around the ward, and singing, art and drama activities enlivened the previously colorless and largely silent hospital environment.

During my fieldwork, I encountered many other, similar depictions of hospitals, from volunteers, volunteer coordinators and medical practitioners. Czech hospital treatment was very advanced, I was told, at treating the medical problems of the population at large, but it was inadequate at acknowledging or addressing the personal, social and emotional experience of ill health and treatment. Of course, critique of non-holistic, de-personalized medical models of patient care are not unique to the Czech Republic (see for instance Boschma 1997). What was particular was how such representations of the problems with medical hospital practice were so directly linked to representations of the socialist state. As the founder of the volunteer program above explained to me, the Marxist-Leninist underpinnings of state socialism privileged a materialist account of history and society, which profoundly impacted on how hospital care was organized. It focused on the material; on the treatment of physical, biological bodies, but not on the individual person and their social experience of ill health. This orientation also reinforced the authority of medical professionals (already wellestablished in the pre-socialist period) as part of a more general ideological commitment to a 
progressive modern society in which scientific knowledge (as opposed to backward religious ideas, for example) underpinned approaches to caring for the health of citizens. Some comments from a nurse in one of the hospitals in my study illustrate this point:

At the beginning of the last century, the doctor was an authority for patients. What the doctor said - that was true...After the [second world] war, the situation changed...I put it down to the [socialist] regime here, which gave precedence to institutional care. And I think lots of nursing staff got the idea that...they didn't feel the need to discuss things with patients. This wasn't something completely wrong, there were good intentions [behind it], but people were not informed. [It was rather a case of] "I’m the doctor and you're the patient, I have declared something you will obey."

The nurse referred here to the tendency for health and care services to be provided through, and concentrated within, large institutions (hospitals, residential homes for mentally and physically disabled, old people's homes) in which medical authority was concentrated. Such institutions were represented as places in which residents or patients were directly exposed to state authority in the guise of scientific, medical expertise. Volunteer coordinators often described hospitals as if they were other worlds that cut patients off from 'normal' life and everyday interaction. The project of initiating and establishing volunteer programs was one that aimed to bring the world of the hospital and the world of everyday life outside it together, thereby (as volunteer coordinators put it) 'humanizing' health care.

These images of the state as embodied in authoritative medical practice and health institutions did not only feature in the accounts of volunteer coordinators, civil society activists and health professions. They had wider resonance amongst volunteers, many of whom chose to become involved in the programs following difficult or traumatic personal experiences of hospital care. Volunteers were inspired by the idea that patients undergoing 
intensive or residential hospital treatment needed additional support - personalized care and attention - that volunteers could provide but doctors and nurses could not.

Thus the programs aimed to provide a form of care that was distinct from that of medical professionals and the state. Volunteers' approach to care was not expert, but lay. It was not scientific, but based on volunteers' feelings of altruism and compassion for patients. In promotional literature, written guidance, and discussions with volunteers and hospital staff, coordinators repeatedly presented volunteering as a lay form of personalized, social or emotional support, quite different from patient care based on specialist medical or nursing knowledge. Volunteers were advised not encroach on the tasks of medical personnel (for example by querying patients' diagnoses or treatment), and to be wary of requests to perform tasks such as feeding, washing, or dressing patients. Volunteers were not to be treated merely as an unpaid workforce, but recognized as individuals giving up their free time to support patients in a unique, non-medical manner.

Several important observations may be made at this point. The volunteering programs aimed to bring into being a new division of caring labor - to complement existing care that was expert and expressive of state authority (doctors and nurses) with the care of civil society (volunteers). But these two forms of care were not envisaged as antagonistic, or constructed as competing with each other. To this extent, the vision of volunteering in this case differed from pervasive discourses of volunteering and welfare found in the UK or the USA. Volunteering in these contexts, as recent studies have explored, may often be co-opted or mobilized as part of a wider neoliberal discourse aiming to 'empower' individual citizens against an 'over-bloated' state welfare system that has supposedly trapped them in passivity, disengagement, or dependency on state hand-outs (e.g., Fyfe and Milligan 2003; Hyatt 2001; c.f. Fraser and Gordon 2002; Kingfisher 2002,). By contrast, in the Czech case, notions of volunteer 'empowerment' against an ineffective, under-performing (welfare) state in the form 
of health care did not feature in narratives of the benefits of volunteering. Hospital volunteering was not projected as an alternative to the care of doctors and nurses, nor did those promoting it even seek to radically alter hospital care. Although critical of hospitals and medical professionals at times in ways explored above, volunteer coordinators were not aiming to significantly challenge how they worked, and most of the time accepted that hospital care could not be other than it was. Justifications for hospital volunteering affirmed the existing representations of hospital care as a professionalized, expert practice of state authority. Thus despite institutional reforms to health care, which had greatly facilitated the entry of civil society actors into this arena and created an appearance of distance between central government and health services, hospital volunteer programs justified their existence by drawing upon an older, more widely recognized, more coherent image of hospital care and medical practice as inevitably of the state (c.f., introduction to this volume).

Producing hospital volunteering as civil society, i.e., not the state, entailed the affirmation of difference, of a clear boundary between hospital care (as the state) and volunteered care (as civil society) (Mitchell 1991). The production of this boundary enabled supporters of hospital volunteering to produce a coherent narrative of its purpose as independent civil society, rather than a mere appeal to the general public to perform unpaid labor in support of hospital services. This process parallels that described by Thelen, Vranjes and Thiemann (this volume) in which the care provided by workers in Serbian state-funded elder care programs becomes acceptable when understood through the ideology of kinship, which simultaneously serves to uphold discourses of the state as distant or inadequate.

Nonetheless, making hospital volunteering programs successful as civil society required a great deal of effort, support and resources. The willingness of citizens to give up their time to volunteer was crucial, but so too were salaries and office space for coordinators, computers, telephone lines, promotional materials (posters, signs, websites), and the support 
and cooperation of hospital staff. In what follows, I explore more concretely three arenas of hospital volunteering, focusing on how representations of civil society and the state, and negotiations over the flow of resources, were produced in relationships between key actors, volunteer coordinators, hospitals managers and local government officials.

\section{Gaining Hospital Management Support: Prague}

The volunteer program within a large university hospital in Prague was in many ways the most successful of the three I studied. It had developed rapidly, beginning with the activities of a group of people attending the Adventist church that lay within the hospital grounds, but that was in other ways unconnected with routine hospital business. This church group ran a charitable bazaar to raise money to buy small presents for hospitalized children on various wards, which were distributed to the children as part of the annual St Nicolas festivities in early December (Mikuláš). In 2005, the group formed a civil association (občanské sdružení), and with the support of both the hospital management, began to run a volunteer program in the hospital in July that year with six trained volunteers. By the end of the year they had thirty trained volunteers, as well as a website and office space in the hospital. At the end of 2007, the center managed seventy volunteers who actively visited patients on hospital wards at least once a month and had trained a total of eighty volunteers in that year.

The key relationship sustaining the volunteer program was that between Iveta and the hospital's deputy director. Iveta wished to develop charitable and civil society activity within the hospital, initially mobilizing her congregation to this end but soon involving a wider range of people with no necessary religious affiliation in her endeavors. Her activities and future plans required access to patients on hospital wards and therefore the explicit support of the hospital's senior personnel. Prior to meeting Iveta, the Deputy Director had been seeking to develop non-medical, therapeutic forms of care for long-term hospital patients on the 
children's neurology and geriatric wards, but had encountered opposition to this from her senior colleagues and limitations to the budget for hiring therapists. Instead of paid professionals, she perceived that a volunteering program could also potentially improve longterm patients' wellbeing, but this required a dedicated activist willing to establish and manage such a venture. On meeting and recognizing their shared interests, the two women developed a close working relationship, meeting regularly to discuss the development and expansion of the new volunteer program.

The Deputy Director assisted Iveta's work in two key ways. Firstly, she insisted that doctors and particularly nurses cooperate with the new volunteering program, by allowing volunteers onto their wards. In theory, senior ward staff had a choice of whether to accept volunteers or not. Behind the scenes, the Deputy Director exerted strong pressure on her colleagues managing wards with significant numbers of long-term resident patients to admit and work with volunteers. Thus it was that the head nurse of the geriatric ward, who had initially been highly skeptical about the purpose and value of volunteering, told me that it had been "impossible to resist the Deputy Director." Since acquiescing to the presence of volunteers, she had also come to appreciate them, in particular, a volunteer who provided a weekly class for dementia patients aimed at retaining memory and physical skills, and others who came to sing for, or with, patients, or took them outside into the hospital grounds for some fresh air. Already over-stretched staff could not undertake such activities with patients, she explained.

Secondly, the Deputy Director ensured that from 2006 onwards, the hospital provided a full time salary for Iveta, as well as office space, desks, telephone lines and computers for a new volunteer center within hospital grounds. In providing this core funding, the stability and continuity of the volunteer program was guaranteed. It gave Iveta and her colleagues both paid time and office resources to apply for additional funding, not as hospital employees, but 
as a civil association, which had already been formed and granted legal status in the previous year. Using this status, Iveta made annual applications to the Ministry of Health and the Ministry of the Interior under funding schemes specifically for civil society organizations. In 2007, her civil association was awarded 270,000Kcs (£10,000) from the Ministry of Interior. Since salaries, office space and other essentials were already covered by the hospital, such grant money (alongside money from commercial sponsors - also relatively successfully obtained) could be spent exclusively on materials and activities that allowed the volunteer center to enhance its own public visibility as a distinctive organization, located within the hospital, but also autonomous from it in terms of its function and mode of operation. Grant monies paid for the T-shirts worn by volunteers on visits to wards, which featured the civil association's own logo. It covered the costs of creating and maintaining the center's web site, public lectures, workshops and training for coordinators as well as the furniture for and the refurbishment of the office space in which the center was housed. Here the spacious, brightly painted rooms with comfortable sofas and places to sit and drink tea and coffee certainly felt quite distinct from the somewhat dilapidated external appearance of the rest of the hospital. Grants to the civil association were used to generate a distinctive physical space for the center and strong visibility for its work throughout the hospital and beyond. This supported volunteers' sense of belonging to a unique project that was in, but not of, the hospital. That the center appeared modern, clean, friendly but also well organized, with a full and varied program of events and activities, also added to its appeal to volunteers.

The atmosphere of the volunteer program as a vibrant and autonomous project of civil society within the Prague hospital manifested a vision shared by Iveta and the Deputy Director of the benefits of volunteering for hospital patients. Significantly, this vision affirmed not only that professional hospital care had its limits, but also that civil society could step in to meet the needs for which hospital medicine was ill equipped. Agreeing on this 
vision of the state-civil society boundary, the two actors worked together to maximize the possibilities for channeling resources into volunteering. The reformed, de-centralized structure of health care that provided hospital managers with scope to develop new collaborations, alongside the post-1989 legislative context and funding mechanisms for civil society, were key prerequisites for this.

\section{Engaging Local Government: Ostrava}

In the industrial city of Ostrava and its surroundings in northeast of the Czech Republic, I examined a rather different model of hospital volunteering to that in Prague. I focused on the local branches of the international humanitarian organization ADRA (Adventist Development and Relief Agency) ${ }^{2}$. ADRA was originally founded in 1956 in Maryland, USA, as a nonprofit agency providing community development and disaster relief, and it now has branches and projects the world over. It began to be active in the Czech Republic in 1992, where it now has ten volunteer centers, each in different cities. Two of ADRA's key goals are to promote health and work with vulnerable people. Although providing disaster relief around the world is a key aim of the organization globally, Czech ADRA volunteer centers focused on promoting volunteering in health and social care organizations. ADRA's religious foundations and leadership did not, by and large, permeate their locally- and regionallyfocused activities in the Czech Republic. Most of the ADRA activists in Ostrava and Frýdek were not Adventists (some were not religious at all, others were Catholic), nor did they promote religion or work exclusively with religious clients.

ADRA's local mode of operation was quite different to the Prague case. Rather than seeking exclusive partnerships with a particular hospital, ADRA volunteer coordinators aimed to support the development of volunteer programs across a wide range of different health and social care institutions in the city. They did so on a consultative basis following a 
prescribed model. Specifically, ADRA volunteer coordinators encouraged contact from any hospital or care home interested in establishing a volunteer program. In initial meetings, ADRA coordinators discussed practical possibilities for volunteering with the hospital or care home management. If these early negotiations progressed a distinctive partnership would be established between the two parties. ADRA produced publicity to generate interest in the proposed volunteer program, but left it to the hospital/care home to distribute this. Training days for volunteers were run by both ADRA and key personnel from hospital/care home, with ADRA representatives running presentations on the purpose and function of volunteering, and hospital/care home staff providing key information about the nature of their patients or clients and the specific kind of help required (e.g., which kinds of wards). Interested volunteers were then interviewed by a panel consisting of both parties. Once a group had passed the interview and been selected, ADRA ran monthly volunteer supervisions, but otherwise left it to the hospital/care home to coordinate the program on a day-to-day basis. Aside from covering its own expenses in this process, ADRA did not seek money from hospitals in return for its assistance, and encouraged hospitals to invest available resources in the program itself.

At the time of my research, activists associated with the ADRA volunteer center in Frýdek-Místek (a town close to Ostrava) were exploring the possibilities of opening a new volunteer center in Ostrava itself. Hana was the Ostrava-based ADRA volunteer coordinator, and later in 2009 she became the Director of the new ADRA volunteer center in the city. When I met her she was managing two volunteer programs in two separate hospitals, as well as a number of others in old people's homes and a residential facility for the mentally ill. These programs had a combined total of eighty registered Ostrava-based ADRA volunteers in the year 2007. ADRA therefore already had a strong local presence and visibility, and was one of several large global charities operating volunteering programs in the city. Hana 
nonetheless sought to strengthen and consolidate ADRA's local influence, not only by expanding contacts with health institutions, but also by nurturing those with local government officials.

Like other regional authorities, Ostrava City Council had drawn up a Community Social Service Plan (Komunitní Plán Sociálních Služeb) for 2007-2010, which sought to map its population's different needs for care and support, and then coordinate and mobilize a range of public, private, and charitable organizations towards meeting these needs (Ostrava Municipal Authority 2007). Recognized within this document, which set budgets against current and future service provision, was the need to expand the range of health and social care services on offer to local people beyond large facilities (such as hospitals, care homes and old people's homes). Widening care provision alternatives was a local government priority, and promoting volunteer programs that provided such alternative forms of care was of particular interest to city officials. Thus civil society organizations that already ran volunteer programs were invited to work in partnership with city authorities to achieve the goals of the plan. To this end, a roundtable committee of representatives from charitable and non-profit organizations working with volunteers was held monthly, chaired by a local government official, and tasked with developing shared strategies for expanding and promoting volunteering.

Hana saw this as an important forum through which ADRA could retain its public reputation and strengthen its influence over the future direction of volunteering programs in the city. She and her colleagues used this forum to emphasize ADRA's specific experience in working with volunteers, pointing out ADRA's competence as a leader in the field, in comparison with other (competitor) organizations on the committee. For instance, the two largest charities on this committee in terms of both funding and numbers of volunteers were ADRA and Caritas (Charita), an international Catholic charity that also ran volunteer 
programs at hospitals and care homes in Ostrava. Aside from this were members of smaller organizations working with groups of people that attracted far fewer numbers of volunteers, e.g., economically disadvantaged families, excluded young people, and Roma. The municipal authorities had given one of these smaller organizations responsibility for acting as an umbrella organization for all volunteer programs in the region, providing interested citizens information about the full range of volunteering opportunities available, and directing them to the program matching their interests. During a committee discussion of these arrangements, one of Hana's ADRA colleagues criticized this umbrella organization for being “undemocratic” by advertising its own programs but failing to advertise ADRA's. He added that the umbrella organization was ineffective at recruiting volunteers, and that it seemed inappropriate that it pose as the body sending ADRA volunteers, when ADRA was so successful at its own independent volunteer recruitment. This criticism was aimed at drawing the committee's attention to ADRA's successes, whilst also highlighting ADRA's independence from local state structures, as well as the dependence of the city on large organizations such as ADRA for achieving its community care plans objectives. In response the official chairing the meeting emphasized how much others could learn from ADRA, and invited written responses to review current arrangements.

Hana also sought out informal routes through which to gain resources from the city authorities. These relied on direct appeals to powerful officials and elected representatives within regional government, via personal contacts and relationships. For instance, Hana had participated in a meeting with Ostrava's mayor at which she asked for his support in securing an office space for the new volunteer center. She requested either financial help with the rent or provision of a city-owned office with reduced rent. The mayor was open to this request and inclined to help. The meeting itself had been arranged via another contact who was close to the mayor, and this, Hana explained, greatly advanced her chances of getting his support. 
without making ADRA publicly appear too close to (or dependent on) local government. As a global charity with significant internal resources, extensive marketing and publicity materials, which had also been active in the area for some years, ADRA could project itself as an autonomous civil society organization, whilst simultaneously retaining its significance influence over how the state-civil society boundary was to be drawn and maintained through its relationship with local government.

\section{Lacking Distinction: Ústí nad Labem}

The third site of my fieldwork was Ústí nad Labem, a chemical industry town in the northwest of the country. Hospital volunteering here differed from the previous two cases. This hospital was the largest in a recently founded shareholder company, consisting of a total of six regional hospitals in the area. The hospital paid for office space and the salary of a full time coordinator. Jaromila, the coordinator, had been involved in the promotion of volunteering at the hospital since 2000, formerly as part of her position in the city's volunteer center, then as the hospital's employed volunteer coordinator.

Although the hospital management appeared to support volunteering, at the time of my fieldwork Jaromila was deeply frustrated, disillusioned, and on the verge of quitting her job. Chief among her difficulties was the hospital's lack of infrastructural and promotional support for the volunteer program. The hospital management seemed unwilling to insist that ward-level staff cooperate with the program. Despite her own efforts to persuade staff of the value of volunteering for patient care, Jaromila's volunteers regularly encountered dismissive or indifferent reactions from doctors and nurses. The nurse manager did not require that her staff work with Jaromila and the volunteers (as the Deputy Director in Prague did). Indeed, it was unclear to Jaromila how much the hospital management really wanted the volunteer 
program to grow and prosper - they seemed complacent about the low numbers of active, regular volunteers on the program.

Additionally, volunteering had little visibility within the hospital. There were few notice boards where Jaromila was permitted to attach posters and information about volunteer programs. Although her center had a website, it was buried within the hospital's own larger website and contained little information. Jaromila also had no dedicated budget for her activities, but had to get permission from the hospital director for each piece of expenditure, requests that took days if not weeks to be processed. Jaromila's office was in the main administrative building of the hospital, a place where only hospital employees went (not patients or relatives) and which required a special swipe card. The office could accommodate two people but not more, which made it difficult for her to hold individual meetings with prospective volunteers or supervisions with trained ones.

Finally, the legal status of the hospital as part of a shareholder company prevented Jaromila from applying to government ministries for financial support for her volunteer program (as coordinators in Prague and Ostrava regularly did). As a full time employee of a profit-making hospital, there were also significant obstacles in the way of creating a civil association through which to seek financial support for volunteering in the hospital. Jaromila was almost entirely dependent on the hospital's willingness, or lack thereof, to support her efforts.

Towards the end of my fieldwork in Ustí, things began to look more optimistic for the volunteering program. The hospital directors initially provided a new, more accessible, larger office space, with furniture and a kitchen. They later hired an additional coordinator and later still agreed to expand volunteering programs across the other five hospitals in the company. Jaromila became the overall director of this multi-sited volunteer center, in charge of managing a paid volunteer coordinator at each hospital. However, after a couple of years, 
support for volunteering entirely collapsed following the sudden appointment of a new board of directors at the hospital, that failed to see any value in hospital volunteering, closed all six programs down and laid off Jaromila.

Ultimately, Jaromila lacked relationships that would have provided her with sufficient material and representational resources to create the hospital volunteering program as a distinctive civil society project. The management's faltering belief in the value of volunteering for patients, evident in their unwillingness to insist on staff cooperation with Jaromila, coupled with their reluctance to allow her sufficient control over the resources she needed to build her program left her isolated. To this extent, she was unable to distinguish her civil society initiative from the image of hospitals as the state. The hospital's legal status as a profit-making company blocked Jaromila from securing civil society status for her program in legal/institutional terms, and seeking resources and support on those grounds. The support that did emerge was relatively short-lived, as the new board of directors took over and devised new priorities. In the absence of relationships enabling her to distinguish her activities from the image of the hospital either as the state (as medical practice and the attitudes of staff on wards), or as a private company, Jaromila struggled make volunteering emerge as autonomous civil society.

\section{Conclusion}

The Czech health care system has been institutionally distanced from central government in the past twenty years. A series of reforms have made hospitals far more legally, financially and managerially autonomous from government ministries than during the socialist period. Yet as this study has shown, hospital care provided by expert medical professionals continues to be widely associated with the socialist state, seen to embody various legacies of how health care was organized and oriented during socialist times. This image of 'socialist' health care 
was affirmed and reproduced as part of the process of developing new forms of volunteered care under the banner of civil society and established in distinction from 'state' care provided by expert professionals.

In this way, discourses of civil society in this case study mirror those of the 1990s in the East Central European region (as explored by Hann 1996; Sampson 1996, Wedel 2001 and Hemment 2007) in their emphasis on the necessary autonomy of civil society from the state. Yet in this instance, the process of state-civil society boundary creation did not promote competition or antagonism between these entities. To this extent, my case differs from earlier civil society discourses of the postsocialist region, as well as from neoliberal experiments in the USA and UK which posit volunteering as an 'anti-government' alternative to an overbloated state (Fyfe and Milligan 2003; Hyatt 2001).

Instead, the process of making volunteering programs coherent as authentic civil society was negotiated through relationships between personnel located in hospitals, NGOs and local government. Their success depended upon a coordinated, visible projection of volunteering as beneficial, valuable and distinctive from the state (an implicit affirmation of the limits of 'state' hospital care on the part of all parties) as well as a secure flow of resources in terms of paid time, materials and managerial support for volunteering. In this way hospital volunteering programs brought into being a new division of caring labor between the expert professionals and lay citizens; one which reproduced widely recognized images of the state, but which also served as an arena for ongoing negotiations over the resourcing of civil society and the maintenance of the line between civil society and the state.

\section{Notes}


${ }^{1}$ The ethnographic fieldwork on which this article is based was carried out between January and July 2008, funded by a British Academy Larger Research Grant (Project title: 'Volunteering Care: The Gendered Politics of Voluntary Networks in Three Czech Hospitals,' ref. 45331). I carried out interviews with volunteers, nurses, doctors, hospital management, and volunteer coordinators, at all three sites; observed and took part in volunteer training and supervision, volunteers' visits to patients, an public events within the voluntary sector. To maintain research participants’ anonymity, all names have been changed.

2 There was no direct relationship between ADRA in Ostrava and the members of the Adventist church, which founded the Prague volunteer centre.

\section{References}

Alexander, Jeffrey C. 2006. The Civil Sphere. Oxford: Oxford University Press.

Boschma, Geertje. 1997. “Ambivalence about Nursing’s Expertise: The Role of a Gendered Holistic Ideology in Nursing, 1890-1990.” Pp. 164-176 in Nursing History and the Politics of Welfare, eds. A. M. Rafferty, and J. Robinson. London: Routledge.

Caldwell, Melissa L. 2004. Not By Bread Alone. Social Support in the New Russia. Berkeley: University of California Press

Clarke, John, Janet Newman, Nick Smith, Elizabeth Vidler, and Louise Westmoreland. 2007. Creating Citizen Consumers. Changing Publics and Changing Public Services. London: Sage

Fraser, Nancy, and Linda Gordon. 2002. “A Genealogy of Dependency. Tracing a Keyword of the U.S. Welfare State.” Pp. 14-39 in The Subject of Care. Feminist Perspectives of Dependency, eds. E. F. Kittay, and E. K. Feder. Lanham, MD: Rowman and Littlefield Publishers 
Frič, Pavol. 2001. Dárcovství a Dobrovolnictví v České Republice [Donation and Volunteering in the Czech Republic]. Prague: NROS, AGNES.

Fyfe, Nicholas R., and Christine Milligan. "Out of the Shadows. Exploring Contemporary Geographies of Voluntarism.” Progress in Human Geography 27, no. 4: 397-413. Hann, Chris. 1996. “Introduction: Political Society and Civil Anthropology.” Pp. 1-26 in Hann and Dunn 1996.

Hann, Chris, and Elizabeth Dunn, eds. 1996. Civil Society: Challenging Western Models. London: Routledge.

Havel, Václav. 1990. Disturbing the Peace. London: Faber and Faber.

Hemment, Julie. 2007. Empowering Women in Russia. Activism, Aid and NGOs. Bloomington: Indiana University Press.

Hyatt, Susan B. 2001. "From Citizen to Volunteer. Neoliberal Governance and the Erasure of Poverty.” Pp. 201-235 in The New Poverty Studies. The Ethnography of Power and Impoverished People in the United States, eds. J. Goode, and J. Maskovsky. New York: New York University Press.

Inglot, Tomasz. 2008. Welfare States in East Central Europe. Cambridge: Cambridge University Press.

Jaroš, Jan, Kamil Kalina, Martin Dlouhý, and Antonín Malina. 2005. “Decentralization and Governance of Healthcare in the Czech Republic in the 1990s.” Pp. 191-272 in Decentralization in Healthcare. Analyses and Experience in Central and Eastern Europe, ed. G. Shakarishvili. Budapest: Open Society Institute.

Kingfisher, Catherine, ed. 2002. Western Welfare in Decline. Globalization and Women's Poverty. Philadelphia: University of Pennsylvania Press.

Mamdami, Mahmood. 1996. Citizen and Subject. Contemporary Africa and the Legacy of Late Colonialism. Princeton: Princeton University Press. 
Marreé, Jörgen, and Peter G. Groenewegen. 1997. Back to Bismarck. Eastern European Health Care Systems in Transition. Aldershot: Avebury.

Mitchell, Timothy. 1991. “The Limits of the State. Beyond Statist Approaches and their Critics.” American Political Science Review 85, no. 1: 77-96.

Ostrava Municipal Authority. 2007. Community Plan of Social Services and Associated Activities in the City of Ostrava to the year 2010. [in Czech.]. Ostrava: Ostrava Municipal Authority.

Read, Rosie. 2010. “Creating Reflexive Volunteers? Young People's Participation in Czech Hospital Volunteer Programs.” Journal of Youth Studies 13, no. 5: 549-563.

Read, Rosie, and Tatjana Thelen. 2007. "Introduction. Social Security and Care After Socialism: Reconfigurations of Public and Private.” Focaal: European Journal of Anthropology 50: 3-18.

Sampson, Steven. 1996. “The Social Life of Projects. Importing Civil Society to Albania.” Pp. 121-142, in Hann and Dunn 1996.

Štich, Zdeněk. 1954. Health Care in Czechoslovakia. Prague: Orbis.

Tošner, Jiří, and Olga Sozanská. 2006. Dobrovolníci a Metodika Práce s Nimi v Organizacích [Volunteers and Methods of Working With Them in Organizations]. Prague: Portál.

Trouillot, Michel-Rolph. 2001. “The Anthropology of the State in the Age of Globalization Close Encounters of the Deceptive Kind.” Current Anthropology 42, no. 1: 125-138. Tutr, Vojtěch, and Jiří Tošner. 2003. “A Legal Milestone for Czech Voluntarism.” Trust for Civil Society in Central and Eastern Europe (15 August). http://www.ceetrust.org/article/106/.

Wedel, Janine R. 2001. Collision and Collusion. The Strange Case of Western Aid to Eastern Europe. New York: Palgrave. 